\title{
Conceptions of Reinhart Koselleck's historical time in the thinking of Michael Oakeshott
}

\begin{abstract}
Summary
In recent times, political theorists have begun to recognise Reinhart Koselleck's practice of Begriffsgeschichte, the study of conceptual history, as a useful approach to studying key concepts in political ideologies and the history of ideas. But his theory of historical time, an integral ingredient to his conceptual-historical project, is often overlooked and underused. In comparing the thinking of Michael Oakeshott with Reinhart Koselleck's theory of historical time, this article brings this theory to the forefront, and looks at their respective approaches to studying the historical past to help unpack Oakeshott's implicit temporal approach to historical understanding. It identifies important convergences and divergences between the two thinkers' theories of historical time, focussing in particular on how we might order time and come to understand the relationship between its tense dimensions. From this, the article argues that their respective promotion of a plurality of historical times is a reaction to the modern politicisation of historical time and a shared critique of radical political change.
\end{abstract}

Keywords: Oakeshott; Koselleck; time; history; modernity; politics.

\section{Contents}

1. Introduction

2. Constructing Temporal Structures of the Past

3. Modernity and the Ideological Politics of Historical Time

4. Conclusion

\section{Introduction}

At first glance, an investigation into Michael Oakeshott's thinking about any sort of 'time' may look like a curious undertaking. Temporality is not a subject to which he devotes any direct attention, nor given his roots in British Idealism, is the attempt to discover an external 'What then is time? ${ }^{11}$ an enterprise he would meet with enthusiasm. ${ }^{2}$ Nonetheless, upon closer inspection the issue of temporality can be seen to flow under the surface of much of his thinking. Like prospectors, we can find references to time scattered across his writings, but his thoughts are most accessible to us in his writings on the practice or mode of historical enquiry, immediately opening up a space for dialogue with others interested in the intersection between time, historicity and its implications for the political.

My aim here is to make one such comparison by linking aspects of Oakeshott's understanding of time and history-how we narrate historical events and navigate the tense dimensions of past, present and future - with Reinhart Koselleck's instructive theory of historical time (Historischen Zeit). Suggesting that Oakeshott, like Koselleck, develops a theory of

\footnotetext{
${ }^{1}$ This phrase is a reference to Book IX of Augustine's Confessions, [IX:17]. Augustine, Confessions (Oxford: Oxford University Press, 2009), 230-231, where he suggests that we know what time is unless we are asked to explain it.

${ }^{2}$ In this, Oakeshott follows the general British Idealist position that a fact cannot exist separate from experience, and that all experience is a world of ideas. For example, in Experience and its Modes he writes that 'the truth or falsehood of a scientific hypothesis is not a question of its correspondence with or discrepancy from a world of fixed and unalterable objects, because no such world is anywhere to be found'. Michael Oakeshott, Experience and its Modes (Cambridge: Cambridge University Press, 1978), 199.
} 
historical time for ordering historical experience, ${ }^{3}$ I narrow my focus to two intersections: first, to compare their respective approaches to historical epistemology, and second, building on this, to look at their views on the practical use of historical time. This is admittedly to fashion a hypothetical space for conversation between the two men. Even though they were contemporaries, neither referenced the other's work, and it is unclear, even unlikely, that either read the other. Koselleck was heavily influenced by Schmitt and Conze, ${ }^{4}$ both familiar to Oakeshott, and is a product of a hermeneutical tradition of Heidegger and Gadamer of which Oakeshott was certainly aware (the former Oakeshott read closely; though the latter perhaps not at all). ${ }^{5}$ Still, as a historian, Koselleck remained, and in many ways remains, obscure to political theorists, and he belatedly emerges on the radar of the Anglo-American academic world in the mid-1980s, soon before Oakeshott's death. ${ }^{6}$ Since then, following the English translation of numerous essays in Futures Past and a further set in The Practice of Conceptual History, Koselleck is mainly associated with the project of Begriffsgeschichte, ${ }^{7}$ the historical study of concepts, and the resulting eight-volume Geschichtliche Grundbegriffe (still mostly untranslated), which catalogues the meaning of a range of historical concepts, particularly on the vernacular level. ${ }^{8}$

But to focus solely on Koselleck's mapping of historical concepts over time is to understate his intellectual contribution and space for comparison. Begriffsgeschichte is associated with a wider reassessment of Heidegger's idea of historicity (Geschichtlichkeit) for investigating

\footnotetext{
${ }^{3}$ For an introduction to Reinhart Koselleck's idea of historical time, one can start with a series of collected essays on Historik. See Reinhart Koselleck, Zeitschichten: Studien Zur Historik. (MIT Einem Beitrag Von Hans-Feorg Gadamer Frankfurt: Suhrkamp Verlag, 2000). In connection with Begriffsgeschichte, see Begriffsgeschichten (Suhrkamp, Frankfurt am Main, 2006). Many of these essays appear in two English translations. See in particular, 'Begriffsgeschichte and Social History', in Reinhart Koselleck, Futures Past: On the Semantics of Historical Time (Studies in Contemporary German Social Thought). Translated and with an introduction by Keith Tribe. (New York, Columbia University Press, 2004), 75-92; 'Time and History', in Koselleck, The Practice of Conceptual History: Timing History, Spacing Concepts. Translated by Todd Samuel Presner and Others. (Stanford: Stanford University Press, 2002), 100-114. Also see Koselleck, 'Introduction and Prefaces to the Geschichtliche Grundbegriffe'. Translated by Michaela Richter. Contributions to the History of Concepts 6:1 (2007), 1-37.

${ }^{4}$ On Schmitt's influence on Koselleck, see Niklas Olsen, 'Carl Schmitt, Reinhart Koselleck and the foundations of history and politics', in History of European Ideas 37:2 (2011), 197-208.

${ }^{5}$ For the influences of Gadamer and Heidegger on Koselleck, see Niklas Olsen, History in the Plural: An Introduction to the Work of Reinhart Koselleck (New York and Oxford: Berghahn Books, 2013), 26-29. Luke O'Sullivan discusses the influence of Heidegger on Oakeshott in Oakeshott on History (Exeter: Imprint Academic, 2003), 229-231; and Oakeshott writes that he has Heidegger in mind when he discusses the different interpretations of history in 'Present, Past and Future', in On History and Other Essays (Indianapolis: Liberty Fund, 1991), 22-23. For a comparison of the thinking of Oakeshott and Gadamer, see Edmund Neill, 'Michael Oakeshott and Hans-Georg Gadamer on Practices, Social Science, and Modernity', in History of European Ideas 33:1 (2013), 1-31, and Kenneth B. McIntyre, 'Prejudice, Tradition, and the Critique of Ideology: Gadamer and Oakeshott on Practical Reason', Collingwood and British Idealism Studies, 16 (2010), 136-166. More broadly, there are clear connections, yet also important differences, between Oakeshott and the hermeneutical tradition's discussions on the subjectivity and contextual nature of knowledge. For a wider look on this relationship, see Terry Nardin, The Philosophy of Michael Oakeshott (University Park: Pennsylvania State University Press, 2001), 5-10, 100-110.

${ }^{6}$ The two main proponents for connecting Koselleck to a so-called 'Anglo-American tradition' are Melvin Richter and Kari Palonen. See Melvin Richter, The History of Political and Social Concepts: A Critical Introduction (Oxford: Oxford University Press, 1997), 124-142; Kari Palonen, 'The History of Concepts as a Style of Political Theorizing: Quentin Skinner's and Reinhart Koselleck's Subversion of Normative Political Theory', in European Journal of Political Theory 1:1 (2002), 91-106; and Palonen 'Rhetorical and Temporal Perspectives on Conceptual Change', in Finnish Yearbook of Political Thought 3 (1999), 41-59.

${ }^{7}$ A number of essays about the influence of Begriffsgeschichte can be found in a special series, 'Contingency and Conceptual Change' in the Finnish Yearbook of Political Thought Vol. 3 (1999). See especially Janet Coleman, 'The Practical Use of Begriffsgeschichte', 28-40.

${ }^{8}$ The Geschichtliche Grundbegriffe, is a collaborative work in eight volumes under the editorship of Otto Brunner, Werner Conze and Koselleck, the only one of the three to see the project through to its conclusion. See O. Brunner, W. Conze and R. Koselleck eds. Geschichtliche Grundbegriffe (Stuttgart: Klett-Cotta, 1972-1997).
} 
transcendental categories in Historik in order to set out fresh theoretical premises for studying the past. ${ }^{9}$ Koselleck's own contribution to historical theory, 'the study of the conditions of possible histories', mulled over in numerous essays from the 1960s-1980s, is to propose formal criteria for studying what he calls the 'temporal structures' of history, found either in the temporal qualities of historical concepts ('progress' being the most obvious) or the structured narration of events, in order to account for historical change. This is to explain how we go about ordering past historical experience from the present, and his theory of historical time functions as one possible solution to this longstanding interpretative problem, creating what he calls an 'anthropological given arc linking relating historical experience with the knowledge of such experience' ${ }^{10}$

Oakeshott, meanwhile, never sets out to write a theory of historical time. His approach to temporality more generally, such as we may interpret it, is on one hand open to varied and on the other hand more selective conceptions of time. ${ }^{11} \mathrm{He}$ is selective in the sense that in various places he rejects positivistic notions of a scientific or natural time in preference for an understanding of time as something internal to us. For example, in Experience and its Modes he tells us that "nature is a timeless world, it neither changes nor evolves...it is static and self-contained and the conception of past and future are inapplicable to it' ${ }^{12}$ Instead, more expansively, time is for him something qualitative and human, conceptualised in the present within the distinct modes of human experience. 'What then is time?' depends on its coherence and uses within different systems of thinking - in history, but also in philosophy, science and poetry - where time can give structure and meaning to human existence. In each mode we may conceptualise time differently (or perhaps not be able to at all), emphasising particular tense dimensions more than others, all of which differ from the future-focused orientation of practical life. ${ }^{13}$

As one of many conceptions of time, a past time or 'historical time' may be seen as both dimensional and sequential. For Oakeshott, it is how we might come to order and comprehend the study of the historical past from the present and also how to explain the sequencing of historical events. By piecing together a possible theory of historical time, I suggest he is in fact making an argument in ways similar to Koselleck, which is a plea for narrating the past, not as one singularized historical time, but as constructions of plural simultaneous and multidimensional historical times. Even if history remains for Oakeshott an ideal whole, a whole world, his theory for studying the past still encourages us to return to what may be called the contingent-bound rhythms of particular, localised historical times. As historians, then, we must eschew positivism or philosophies of history and endeavour to construct a past based on evidence of the contingent

\footnotetext{
${ }^{9}$ Zeitschichten, 99, 110. In 'History, Histories, and Formal Time Structures', he writes that 'theoretical premises must be developed that are capable of comprehending not only our own experience, but also past and alien experience; only in this way is it possible to secure the unity of history as a science'. Futures Past, 94. In 'Wozu noch Historie?' he argues for something similar: 'We are simply lacking a theory, which - if possible - will distinguish our science from the theories of the other social sciences: a theory of historical times... The task will then be to uncover temporal structures that are shaped in accordance with the multiple kinds of historical change. The temporality of historical events and the structures of historical processes can thus organize historical writing - as they organize history itself'. 'Wozu noch Historie?' in Historische Zeitschrift 212 (1971), 1-18. Quoted in Olsen Introduction to Koselleck, 218219.

${ }^{10}$ Futures Past, 93.

${ }^{11}$ See Geoffrey Thomas's argument that Oakeshott's tacit acknowledgement of the reality of time already separates him from F. H. Bradley's dismissal of time as incoherent. See Thomas, 'Michael Oakeshott's Philosophy of History' in Leslie Marsh and Paul Franco A Companion to Michael Oakeshott (Philadelphia: Pennsylvania State University Press, 2012), 97.

${ }^{12}$ Experience and its Modes, 200. For more discussion on Oakeshott, time and nature, see Roy Tseng (2003) The Sceptical Idealist: Michael Oakeshott as the Critic of the Enlightenment (Exeter: Imprint Academic), 221.

${ }^{13}$ For example, Oakeshott writes that 'the world of scientific generalization is a world ignorant alike of past and future as such, it knows nothing of historical time, and recognizes time only within its world, as a means of relating its own concepts'. Experience and its Modes, 113.
} 
relationship between historical events within a particular, not universal, historical identity. This idea of contingent historical times spills over to the political practice and the practical use of historical time. Oakeshott wants us to avoid political change based on timeless principles or artificial views of time in preference for a politics of 'intimation', attuned to the innumerable and localised realities, and the plural histories, related to our present practical existence. Let us now look at how he gets here.

\section{Constructing temporal structures of the past}

Turning to Oakeshott and Koselleck's respective views on historical epistemology, it is important to keep in mind that their approaches to history do not explicitly advocate for a particular method of writing it. Rather, they are interested in the theory of history in a time when the field struggles against charges of radical historicism and is squeezed by positivism on one side and the structures of language on the other. For Koselleck, the interrogation of the temporal structures of history is an effort to open up a theoretical discussion on how historians can maintain a space for the discipline and overcome the tension between an in actu event and its ex-post representation. ${ }^{14}$ Oakeshott's various writings on history, ${ }^{15}$ from his early writing in Experience and its Modes to his much later collected essays in On History, are similarly concerned with the characteristics that define 'the activity of being a historian' ${ }^{16}$ positioning his thinking as a philosophical inquiry into what constitutes a unique and worthwhile understanding of the past. For him, history is "not mere recording...[but] a particular kind of thinking, unlike both science and philosophy, but resting upon the common presupposition of all kinds of finite knowledge ${ }^{17}{ }^{17}$ As a way of thinking, for Oakeshott, history is not something to be philosophised or politicised, the latter a form of 'practical past', but exists for itself as an escape from the practical life. It lacks a purpose other than developing an understanding of past time.$^{18}$ History is to study the past for its own sake, ${ }^{19}$ the study of the historical past from the present and not carried out for the present. ${ }^{20}$ It is a 'dead past, a past unlike the present'. ${ }^{21}$ As such, historical understanding is no more than a constructed

\footnotetext{
${ }^{14}$ See in particular Koselleck, 'Linguistic Change and the History of Events', 649-666.

${ }^{15}$ Oakeshott's thinking on history and the practice of the historian is scattered throughout his writing and lectures. For a selection of writings on the practice of history, see 'The activity of being an historian', in Michael Oakeshott, Rationalism in Politics and Other Essays (1991), edited by Timothy Fuller, revised and expanded edition (Indianapolis, Liberty Fund), 151-183; his description of 'historical experience' in Experience and its Modes, 86-168; history as 'goings-on' in On Human Conduct (Oxford: Clarendon Press, 1990), 101-104; the first three essays in On History, 1128; 'History and the Social Sciences', Institute of Sociology, The Social Sciences, London (1936), 71-81. For an introduction to Oakeshott's approach, see, W. H. Dray, 'Michael Oakeshott's Theory of History' in Political and Experience: Essays Presented to Michael Oakeshott on the Occasion of his Retirement, ed. P. King and B. C. Parekh (Cambridge, 1968), and David Boucher, 'The Creation of the Past: British Idealism and Michael Oakeshott's Philosophy of History', History and Theory 23:2 (1984), 193-214.

${ }^{16}$ Rationalism and Politics, 151-183.

17 'Philosophy of History?', in What is History? and other essays, Luke O'Sullivan ed. (Exeter: Imprint Academic, 2004), 132.

${ }^{18}$ See 'The Whig Interpretation of History', in What is History?, 221.

${ }^{19}$ Experience and its Modes, 106.

${ }^{20}$ Oakeshott writes that from the present, "the past", is a construction we make for ourselves out of the events which take place before our eyes... what we call "the past" appears when we understand current happenings as evidence for what has already happened', Rationalism and Politics, 161. This is similar to Experience and its Modes where writes that 'history, because it is experience, is present...but because it is history, the formulation of experience as a whole sub specie praeteritorum, it is the continuous assertion of a past which is not past and of a present which is not present'. Experience and its Modes, 111.

${ }^{21}$ Experience and its Modes, 102, 106. Oakeshott writes earlier that 'whereever the past is merely that which preceded the present, that from which the present has grown, wherever the significance of the past lies in the fact that it has been influential in deciding the present and future fortunes of man, wherever the present is sought in the past, and wherever the past is regarded as merely a refuge from the present - the past involved in a practical, and not an historical past'. Experience and its Modes, 103.
} 
explanation or organisation of what from the present is the known world of historical experience. To explain the historical past, the historian must avoid attempts to employ philosophy or methods of science to understand the temporal ordering of events. There are no historical processes or laws of historical change. ${ }^{22}$ Instead, the historian must rely only on the collected artefacts and recollected experiences of the past to organise it into something coherent for present understanding ${ }^{23}$ Thought in this way, the past itself does not exist: history is not a re-enactment of the past, as Collingwood claims, but only what we know about the past from the present. ${ }^{24}$ It is simply, 'what the evidence obliges us to believe' ${ }^{25}$ Thus, dimensionally speaking, and in-line with the likes of Bradley, Oakeshott's temporal approach to history can be seen as a form of rigid presentism: ${ }^{26}$ as a world of ideas, there are only present constructions of the past based on the historian's evidence-based judgement. ${ }^{27} \mathrm{He}$ tells us that 'the distinction between history as it happened (the course of events) and history as it is thought, the distinction between history itself and merely experienced history, must go; it is not merely false, it is meaningless' ${ }^{28}$

Koselleck does not think of the temporal dimensions of historicity on these terms. From present historical understanding, he thinks we experience past and future, and in studying the past we encounter others' experienced pasts and futures. In 'Wozu noch Historie?' Koselleck writes that 'the past has passed, irrevocably - and it has not: the past is present and contains future. It restraints and opens up future possibilities, it is present in our language, it influences our consciousness as well as the unconscious, our attitudes, our institutions the way we criticize them' ${ }^{29}$ The past is neither entirely 'historical' nor 'practical', to use Oakeshott's distinctions. ${ }^{30}$ Nevertheless, he agrees with Oakeshott's views on the difficultly of present-bound interpretation. In constructing history, he claims it 'becomes temporalized in the sense that, by virtue of the passing of time it changes at each given present, and with growing distance, it also changes in the past, or better said: history unveils itself in the truth of its day'. ${ }^{31}$ For both, the problem of linguistic comprehension is especially salient. Reading a past discourse, or to use Oakeshott's terminology, the various 'voices' of or 'conversations' between actors, is the predominant form of evidence for to understanding historical experience and change. ${ }^{32}$ Here there is broad agreement between the two. For Koselleck, the "past social and political conflicts must be interpreted and decoded in terms of their contemporary conceptual boundaries, and the selfunderstanding on the part of past speakers and writers of their own language-use'.$^{33}$ In a review of the first volume of E. H. Carr's The Bolshevik Revolution, Oakeshott also makes a clear distinction between the language of historical actors and the historian, something he felt it

\footnotetext{
${ }^{22}$ On History, 78-90, 110-115.

${ }^{23}$ Experience and its Modes, 111.

${ }^{24}$ See R. G. Collingwood, The Idea of History (Oxford University Press, 1994), 282-302.

${ }^{25}$ Experience and its Modes, 107-108.

${ }^{26}$ On Oakeshott's presentism see Geoffrey Thomas, 'Michael Oakeshott's Philosophy of History', 104-110, and David Boucher, Texts in Context: Revisionist Methods for Studying the History of Ideas (Dordrecht: Martinus Nihhoff Publishers, 1985), 61-63.

${ }^{27}$ Experience and its Modes, 112-118.

${ }^{28}$ Experience and its Modes, 93. Quoted in Collingwood's The Idea of History, where he characterizes Oakeshott's conception of the historian as someone who is merely 'organizing his present consciousness', 153.

${ }^{29}$ Quoted in Olsen History in the Plural, 230-231.

${ }^{30}$ In Begriffsgeschichtliche Probleme der Verfassungsgeschichts, Koselleck speaks to history's 'double translation', where, 'an historian is obliged to abstract himself from the present in order to avoid making anachronistic judgements of the past but also to connect the judgements of the past back to present controversies'. Quoted in Kari Palonen, 'Contingency, Political Theory and Conceptual History', in Javier Fernandez Sebastian (2011) Political Concepts and Time (Barcelona: Cantabria University Press), 179.

${ }^{31}$ The Practice of Conceptual History, 167.

${ }^{32}$ For example, see Oakeshott's 'The Voice of poetry in the conversation of mankind', Rationalism and Politics, 488541, or The Voice of Liberal Learning, edited by Timothy Fuller (New Haven, CT, 1989), esp. 'Learning and Teaching', 35-61.

${ }^{33}$ Futures Past, 80.
} 
important to preserve, and a distinction he accuses Carr of forgetting. To remain critical, the historian must differentiate his own language from that of his historical subjects, who 'speak an extraordinary private language... [and] have an idiom in which they make their thoughts known to one another' ${ }^{34}$ The historian is not there to question the truth of a historical statement or to somehow reveal the intentions of the author, but to translate an anachronistic language into something intelligible to the reader.

This is to recognise the reality of a past that can never be understood other than through present perspective, and their respective sympathies for contextualising language suggest that it is a potential area for comparison. However, the limited extent to which Oakeshott engages with a sort of linguistic turn to writing history, or writes much history himself, restricts our space for conversation. A more propitious vein is to look at how 'idioms' or language reflect the 'historical experiences' or 'goings-on', or what Oakeshott also calls the 'individual' or 'events' that must make up a narrative history. For both, history is not simply a combination of utterances: it is the 'science of experience', ${ }^{35}$ as Koselleck put it, and experiences (and therefore history) begin with events (Einzelereignis). ${ }^{36}$

It is here where their epistemological arguments overlap, and for both, theories of historical time provide the toolkit for narrating events and historical change. Inspired by Braudel's idea of the 'multilayeredess of history', Koselleck's temporal approach to historical epistemology endorses thinking of links between events in terms of the possibility of plural (and simultaneous) histories. He presents this by using the geologic metaphor Zeitschichten, representing the synchronic layering of diachronic times,${ }^{37}$ which is analogous to his reoccurring use of the idea of 'the synchronicity of the nonsynchronous' (die Gleichzeitigkeit des Ungleichzeitigen), a concept first employed by Bloch, ${ }^{38}$ which represents histories and temporal strata that coexist at the same synchronic moment yet do not correspond. This layered view demonstrates the varied linking of events and also the simultaneity of the dimensions of past, present and future in synchronic points in time-'any synchrony is eo ipso at the same time diachronic'. ${ }^{39}$ We see this, for example, in his discussion of Albrecht Altdorfer's 1529 painting Alexanderschlacht, depicting Alexander the Great's victory over Darius at the battle of Issus in 333 B.C.E., and its simultaneous reference to the contemporary Turkish siege of Vienna. ${ }^{40}$ Like Altdorfer's painting, historicity becomes inextricably linked with considerations of layered time, both in the use of temporal structures to account for different durations and speeds of historical change and in reference to the simultaneity of the tense dimensions in historical explanation.

Koselleck theorises the layering of time from two different, yet interrelated, starting points, which he discusses in numerous places albeit with varying differentiations. ${ }^{41}$ On one hand,

\footnotetext{
${ }^{34}$ Oakeshott, 'Mr Carr's First Volume', in Luke O'Sullivan ed. The Concept of a Philosophical Jurisprudence: Essays and Reviews 1926-51 (Exeter: Imprint Academic, 2007), 329.

${ }^{35}$ The Practice of Conceptual History, 47. Quoted in Zammito, 'Koselleck's Philosophy o Historical Time(s)', 129.

${ }^{36} Z$ Zeitschichten, 43. Likewise, Oakeshott writes that it is only experience that exists. See Experience and its Modes, 5455, 110. For Oakeshott on experience see Thomas, 'Michael Oakeshott's Philosophy of History', 98-99.

${ }^{37}$ Zeitschichten, 9.

${ }^{38}$ See Ernst Bloch Erbscbaft dieser Zeit (Zurich: Oprecht \& Helbling 1935).

${ }^{39}$ The Practice of Conceptual History, 30.

${ }^{40}$ Futures Past, 9-25. For an excellent analysis of Koselleck's discussion of Alexanderschlacht, see Jordheim, 'Against Periodization' in History and Theory 51 (May 2012), 158-160.

${ }^{41}$ In his review of the collected volume Zeitschichten: Studien zur Historik, John Zammito calls him a 'veritable literary "hedgehog", who 'worries his big idea over and over again'. John Zammito, 'Koselleck's Philosophy of Historical Time(s) and the Practice of History', History and Theory 43 (February 2004), 126. As Jordhiem has forcefully argued, it would be a mistake to consider historical time as a separate enterprise from the study of historical concepts. See Helge Jordheim, 'Does Conceptual History Really Need a Theory of Historical Times?', Contributions to the History of Concepts 6:2 (winter 2011), 21-41, and 'Thinking in convergences - Koselleck on language, history and
} 
this theory is a product of his own conceptually-evidenced thesis of modernity that social conceptions and orderings of time newly historicise during a so-called saddle period (Sattelzeit) between 1770-1830. On the other hand, it is a broader theoretical proposal for twentieth century historical practice. ${ }^{42}$ In the first instance, evidenced by the use of concepts like 'progress', 'crisis' and 'revolution', Koselleck claims that a new understanding of time (Neuzeit) emerges during the Sattelzeit, first in historical writing and subsequently moves into political discourse. Starting with the eighteenth century German historian Johann Martin Chladenius, historical writing and individual and social historical consciousness no longer corresponds either to a natural time (such as the cycle of seasons), or a mapped past-future (as in eschatology), or simply thinking of history as a chronological chain, but undergoes a new form of temporalization (Verzeitlichung). In modernity, a new expressly historical time emerges when time is 'subjectively enacted by humans' in the form of constructed history (Verfügbar) where events are narrated in order to contest or upset hitherto accepted orderings of time. In doing so, history in modernity shatters the continuity and predictability of time and, as I will explain in more detail below, emphasises future-oriented horizons of expectation over past experience. ${ }^{43}$

But the subjectivity of contested historical time leads to two problems for history in Koselleck's post war intellectual milieu: the rise of historical 'singularization' on one hand, and on the other (as a consequence) an increasing rejection of representing historical time as a diachronic process at all, in preference for studying history and its concepts purely synchronically. In his theoretical essays, Koselleck's response is to try to broaden this idea of historical time, encouraging historians to recognise the layered planes of historicity extending 'Janus-faced' backwards and forwards across time from one synchronic moment. ${ }^{44}$ Koselleck offers two ways to arrive at a theory of plural historical times. One theorises historical time based on structures of repetition; that is, how historians construct formal diachronic narratives linking one synchronic event to events before and after (Synchronen und Ereignissen). The other we can call categorical, an approach to understanding moments of historical change from studying the shifting temporal perspectives of historical agents themselves (individuals, groups or institutions) by applying the Gadamer-inspired metahistorical categories of the 'space of experience' (Erfahrungstaum) and a 'horizon of expectation' (Erwartungshorizont). ${ }^{45}$

time' in Ideas in History 2:3 (2007), 65-90. Also see Kari Palonen 'Rhetorical and Temporal Perspectives on Conceptual Change', 49-53. To summerise Jordheim, Begriffsgeschichte is a rare approach to the study of language that in response to Saussure's focus on language as a synchronic system attempts to maintain a link between studying the structure of historical language and the diachronic structures of history (Strukturgeschichte). Koselleck argues that studying language synchronically is mistaken in ignoring the possible historical influences on language, on one hand, and the impact of language upon history, on the other. See Koselleck and Gadamer, Hermeneutik und Historik, Sitzungsberichte der Heidelberger Akademie der Wissenchaften, Philosophisch-historische Klasse, Jahrgang 1987, Hericht 1 (Heidelberg, 1987); Koselleck, 'Erfahrungswandel und Methodenwechsel: Eine historische-anthropologische Skizze', in Historische Methode, Christian Meier and Jörn Rüsen, Theorie der Geschichte, Beiträge zur Historik vol. 5 (1988), 13-61; 'Social History and Conceptual History', in The Practice of Conceptual History, 25; and 'Linguistic Change and the History of Events', in Journal of Modern History vol. 61 (December 1989), 649-666.

${ }^{42}$ This is a period where concepts reveal a 'denaturalization' of time, a shift demonstrated by concepts like 'progress', 'revolution' and 'crisis'. Koselleck writes, 'The hypothesis of a denaturalization of the historical experience of time, which also affects the semantics of socio-political expressions, is supported by the emergence of the modern philosophy of history, which appropriates these terms'. The Practice of Conceptual History, 4-5. On modernity, see 'The Eighteenth Century as the Beginning of Modernity', The Practice of Conceptual History, esp. 160-165.

${ }^{43}$ For an explanation of this modernity thesis, see Aledia Assmann, 'Transformations of the Modern Time Regime' in Chris Lorenz and Berber Bevernage, Breaking up Time: Negotiating the Borders between Present, Past and Future (Göttingen: Gandenhoeck and Ruprecht, 2013), 39-56.

44 'Introduction and Prefaces to the Geschichtliche Grundbegriffe', 9.

${ }^{45}$ This is an attempt to reconcile two different strands in Koselleck's theory of historical time. One pertains to the conditions of possible history based on the categories of 'experience' and 'expectation', which reveal historical time (see Futures Past, 262) and the other in terms of the temporal layers and repetitive structures of history (see Futures Past, 95). Others interpret this differently. Niklas Olsen notes that it is unclear as to how these two strands relate to 
Let me briefly explain these approaches. Historical time as a structure of repetition relates to Koselleck's deeper categorisation of experience. He tells us in The Practice of Conceptual History that historical experiences can occur first as a 'surprise', that is, something differentiated from or unexpected based on antecedent experiences. Second, they can be part of a collection of experiences, the result of accumulation that confirms a pattern of events through, for example, institutions or traditions. Lastly, experiences may occur over the long term, 'beyond all spontaneous effects and unexpected turns', thereby greatly modifying the previous framework of new and repeatable experiences. This differentiation then helps us structure 'experience' into 'temporal experiences', where history is layered, multidimensional and multi-durational, consisting of innumerable temporal structures that are both 'internal to and demonstrable in related events'. ${ }^{46}$ In Futures Past, he puts this slightly differently, arguing that histories consist of single events (not just a surprise) where each has a designated before and after (Vorher und Nachher), repeated events, and thirdly, the temporal dimension of the synchronicity of the nonsynchronous (Gleichzeitigkeit der Ungleichzeitigen) where he comments on the 'diversity of temporal strata' found in history, including 'varying extensions of time' and the 'prognostic structure of historical time'. ${ }^{47}$ The idea of the synchronicity of the nonsynchronous is to remind us that history always extends in innumerable strands-shorter durations and longue dureecontaining "numerous differentiable layers which each undergo change sometimes faster sometimes slower, but always with varying rates of change' ${ }^{48}$

Koselleck's categorical approach to historical time has a different focus. While the layers of time can refer to the historian's discovery of short-, medium- and long-term structures, historical time also refers to narrating the past through investigating the temporal awareness of historical actors and societies in order to help identify moments of historical change. ${ }^{49}$ For this, as it were, more first-person understanding of time, Koselleck encourages us to see historical time through applying the anthropological or metahistorical categories of experience and expectation, ${ }^{50}$

each other. See Olsen, Introduction to Koselleck, 230-231. Alexandre Escudier argues that following the prelinguistic aspects of historical time (such as 'birth and death', 'in and out', 'master' and 'slave'), what Koselleck calls 'historical time proper' is deduced from the dichotomy of 'before' and 'after' leading to three levels of analysis. Historical time is constituted in terms of (1) the individuality and repeatability of historical events (identifying continuity and discontinuity); (2) the 'generativity' of history in terms of its relation to succession, socialization and politicization; (3) the history built through applying the categories of 'experience' and 'expectation'. See Alexandre Escudier, 'Temporalization and Political Modernity', in Political Concepts and Time: New Approaches to Conceptual History, Javier Fernández Sebastián ed. (Santander: Cantabria University Press), 131-163.

${ }^{46}$ See 'Transformations of Experience and Methodological Change', The Practice of Conceptual History, 45-83. For a fuller discussion on Koselleck's science of experience, see Luca Scuccimarra, 'Semantics of Time and Historical Experience: Remarks on Koselleck's Historik', in Contributions to the History of Concepts 4 (2008), 162-163.

${ }^{47}$ Futures Past, 95.

${ }^{48}$ Zeitschichten, 330. Quoted in Olsen, Introduction to Koselleck, 226.

49 'There is no history which could be constituted independently of the experiences and expectations of active human agents' he writes, and later adds that the categories are 'suitable for detecting historical time in the domain of empirical research...they are indicative of the temporality (Zeitlichkeit) of men', Futures Past, 256, 258. And he writes elsewhere that 'Historical time, if the term is to have a meaning, is tied to social and political unites of action, to particular acting and suffering human beings, and to their institutions and organizations'. The Practice of Conceptual History, 110.

${ }^{50}$ See Koselleck, Futures Past, 255-275. In The Practice of Conceptual History he also describes this at length. 'Historical times can be identified if we direct our view to where time itself occurs or is subjectively enacted in humans as historical beings: in the relationship between past and future, which always constitutes an elusive present. The compulsion to coordinate past and future so as to be able to live at all is inherent in the human being. Put more concretely, on the one hand, every human being and every human community has a space of experience out of which one acts, in which past things are present or can be remembered, and, on the other, one always acts with reference to specific horizons of expectation...investigating this relationship of specific experiences and expectations [helps us] get a grasp on historical time. That historical time occurs within the difference between these two temporal dimensions can already be shown by the fact that the difference between experience and expectation itself changes - that is, it is specifically historical'. The Practice of Conceptual History, 111. 
influenced by Gadamer's notion of one's historio-experiential 'situation' and 'horizon'. ${ }^{11}$ Put briefly, the 'space of experience' is a contextual reworking of what is recalled consciously or subconsciously by actors, through their own personal experiences or those passed down generationally, while the 'horizon of expectation' is a present anticipation of the future in the forms of hope, fear, prognosis or anticipation..$^{52}$ As changes in conceptual meaning demonstrates that the relationship between the two categories is not static: in their shifting emphasis within first-person outlooks they reveal that the past and future split and redouble on each other, often in an unequal manner, showcasing historical time's capacity for alteration. ${ }^{53}$

Returning back to Oakeshott, for him, the intelligibility of historical change in different 'passages of occurrences', ${ }^{54}$ involves a theory of historical 'reasoning' in order to explain how a particular historical event came about within the world of historical events that comprise a single ideal whole. Doing so is a two-step process ${ }^{55}$ The historian must first individualise an event by identifying a before and an after for the purposes of differentiation. ${ }^{56}$ Describing change between these significantly related events, the second step, is the essence of historical explanation. History is 'an explanation of the world in terms of change, and an explanation of change in its world' ${ }^{57}$ It is there 'to mediate one circumstance to another' ${ }^{58}$ or as he explains more fully, 'the historian's aim is to see as interconnected the details with which he is dealing. His business lies equally with discovery of details and the discovery of their interconnection, for these discoveries are in reality a single discovery' ${ }^{59}$ Like Koselleck, Oakeshott's theoretical challenge is to find a legitimate way to explain significant relationships between events to account for a historical time. His solution to this problem is a unique view of contingency, which is for him the natural relationship between events, or what he calls in Experiences and its Modes 'the unity or continuity of history' ${ }^{60}$ For Oakeshott, unlike Koselleck's category of experience as a surprise or Bury's idea of historical facts as chance occurrences,${ }^{61}$ his idea of contingencies are goings on that 'are composed of related circumstantial occurrences'. The historian is simply 'composing an intelligible continuity of conditionally dependant occurrences' ${ }^{62}$ This is not because events just come after the other, or

\footnotetext{
${ }^{51}$ For instance, Gadamer says that "Every finite present has its limitations. We define the concept of "situation" by saying that it represents a standpoint that limits the possibility of vision. Hence essential to the concept of situation is the concept of "horizon". The horizon is the range of vision that includes everything that can be seen from a particular vantage point'. Truth and Method, Second and Revised Edition, Translation revised by Joel Weinsheimer and Donald G. Marshall (London and New York: Continuum, 2004), 301-303.

${ }^{52}$ Futures Past, 259.

${ }^{53}$ Futures Past, 263.

${ }^{54}$ On History, 1.

${ }^{55}$ In Experience and its Modes he tells us that 'history accounts for change by offering an account of change', and is comprised of no more than events. Experience and its Modes, 143.

${ }^{56}$ Here, an individual event is an inferred or imagined past occurrence that is different from the antecedent happenings to which it is significantly related-a 'conflation of accessories' with 'no exclusive characters but [they] are the difference the made in a convergence of differences which compose a circumstantial historical identity'. On History, 103.

${ }^{57}$ Experience and its Modes, 125.

${ }^{58}$ Rationalism and Politics, 183.

${ }^{59}$ Experience and its Modes, 143. In 'The activity of being an historian', he says something similar: 'in the "historian's" understanding of events, just as none is "accidental", so none is "necessary" or "inevitable". What we can observe him doing in his characteristic inquiries and utterances is, not extricating general causes or necessary and sufficient conditions, but setting before us the events (in so far as they can be ascertained) which mediate one circumstance to another'. Rationalism and Politics, 172.

${ }^{60}$ Experience and its Modes, 141.

${ }^{61}$ See Bury's essay, 'Darwinism and History' (1909), in Darwin and Modern Science, A. C. Seward ed. (Cambridge University Press, 2009), 529-542. For Oakeshott's rejection of Bury's idea of contingency as an accident, see Experience and its Modes, 140 and On Human Conduct, 102.

${ }^{62}$ On Human Conduct, 104. In On History he writes something similar, describing contingency as, 'the kind of relationship which, when in an historical enquiry it is found to subsist between antecedent events and a subsequent event, composes an identity which may be described alternatively, as an event properly understood as an outcome of
} 
relate causally, but because they 'touch'; that is to say, what came after is a response, not a chronological or causal link, to what came before. ${ }^{63}$

To help mediate this contingent relationship between individual events, Oakeshott proposes historians employ two formal (temporal) categories to identify events, that of 'continuity' and 'change'. In Experience and its Modes, Oakeshott describes these categories as,

that by which historical events are determined. An historical event is never a mere pointinstant; it is something with a meaning, and something which can maintain itself relatively intact and self-complete. Its capacity for establishing its individuality lies in the discontinuity, the relative breaks which seems to precede it; and its capacity for maintaining its individuality lies in the continuity or relative absence of break, which it can show. ${ }^{64}$

In the dynamism between the two categories, Oakeshott argues that to account for change there must be a degree of diachronic connectivity, a contingent relationship, between before/after events. 'An historical past may be said to be composed of passages of related events of various dimensions, durations and constitutions assembled in answer to an historical question: a past constituted not in terms of its situational immobility but of time and change'. ${ }^{65}$ Here, as Luke O'Sullivan and Terry Nardin have also discussed, Oakeshott relies heavily on Aristotle's Physics, where he believes his notion of continuity to be similar to Aristotle's understanding of 'contiguity', ${ }^{66}$ when 'a whole is composed of distinguishable uniform parts which touch one another without interval and hold together in virtue of what they themselves are without extraneous mediation' ${ }^{67}$ Continuity in history, what are structures of historical time, is a 'function of the continuity of its parts'. Sequences of historical events can remain contiguous while also accounting for change over time. In this way, Oakeshott tells us he takes Aristotle's notion of change in the Physics in order to 'translate it into the language of time' ${ }^{68}$ It risks sounding as if

antecedent events, or as an assemblage of events related in such a manner as itself to constitute an historically understood event. I shall call it a contingent relationship'. On History, 101.

${ }^{63}$ History is the explanation of a 'sequential relationship of intelligent individual occurrences where what comes after is recognised to be conditional upon what went before'. On Human Conduct, 104.

${ }^{64}$ Experience and its Modes, 121-122. A similar theme is discussed in On History: 'I have argued that the relationship between antecedent historical events and a subsequent recognized as their outcome must be a contingent relationship. And I distinguished this from a relationship of "change", from a causal relationship and from a relationship in terms of something called in from the outside, the glue of normality or the cement of general causes. I shall now argue that the identity in terms of which an assembled passage of historical events, recognized as differences, may be understood as a passage of change is nothing other than its inherent continuity; this continuity to be distinguished from some changeless item in the situation, from and enduring purpose or end to be realized and from the normalities or the "law" of the process of change'. On History, 122.

${ }^{65}$ On History, 68.

${ }^{66}$ See On History, 122, where Oakeshott cites a passage from the Physics (V, 3, 277a): "The continuous is a kind of contiguity...It is found in things whose nature is such as to make them one when they are in contact". The influence of Aristotle's 'contiguity' on Oakeshott is discussed in O'Sullivan, Oakeshott on History, 245-247 and Boucher, 'The Creation of the Past', 165.

${ }^{67}$ On History, 122. In his lectures on the history of political thought, Oakeshott also considers Aristotle's view of science as a systematic inquiry into what causes a thing to behave and the nature of things; and also an inquiry into the 'circumstantial or contingent relations between different things; the accidents that happen to them, or (in the case of men) the designs they may have and carry out'. The later is a historical, not philosophical enquiry, says Oakeshott. See 'Aristotle (1)' in Terry Nardin and Luke O'Sullivan eds. (2006). Lectures in the History of Political Thought (Exeter: Imprint Academic), p. 105.

68 'Change', 13. Quoted in O'Sullivan, 246. In On Human Conduct he claims that history can be best 'understood as the continuity or the continuousness of the passages of differences; continuity being recognized as a kind of contiguity. And an historical past may be identified, alternatively, as an assemblage of antecedent historical events contingently related to a subsequent historical event, or as an assembled passage of antecedent differences which, in virtue of its 
Oakeshott wants to distil history as a whole down to a single account of the past in as minute detail as possible. What rescues him from this problem is the conception of 'identity', which in the Physics Aristotle pairs with contiguity, where according to Oakeshott, 'a succession of occurrences...may be recognised to be "change" if it is continuous and solely in virtue of its continuousness... That is "continuity" of change is itself a form of identity or sameness'. If history is done properly, then, the historian is said to have created within the world of history one of many possible accounts of a 'continuity of change' ${ }^{69}$

Several issues emerge here. For both Koselleck and Oakeshott, it is clear that pluralisation is preferable to singularization. For Oakeshott, the world of history as a whole need not consist of one identity, but can be comprised of innumerable histories of different durations that make intelligible a series of contingent events. A more difficult issue to resolve, however, is whether identity within the experience of history as a whole might make intelligible a plurality of simultaneous and multi-durational historical times. Put in another way, if history is a whole, can a coherent history remain irreconcilable with the synchronicity of nonsynchronous structures of historical change? On one hand, Oakeshott hints that it can. In On History he tells us that an identity of continuity of change is not an exclusive or consequential relationship between antecedent and subsequent, but simply an 'assembled passage of historical differences (events)'. ${ }^{70}$ And he goes on to say that, 'antecedents are not absorbed in this [the] subsequent but remain eligible to be significantly related to a variety of other subsequents' ${ }^{71}$ The assemblage of antecedents and subsequents may be ordered differently, as long as the contingent relationships in one series do not contradict a relationship in another. Still, we should not take this plurality of contingent identities as identical to Koselleck's much richer multidimensional and multidurational layering. First, in Oakeshott's thinking there is no prognostic structure to historical time because such prognostication is anathema to the historical enterprise. We cannot know about or anticipate events ahead of their antecedents. ${ }^{72}$ Moreover, while contingent relationships can form identities of varying length, with events of varying magnitude, Oakeshott eschews history 'written upon a large scale' as it is 'likely to display change more abruptly'. Historical explanation, for him, is not to account for great or revolutionary changes, but to show the opposite: it is a search for explaining contingent change at its most incremental as an alternative to sweeping historical judgements. He tells us that so-called revolutionary events, watersheds and great leaps forward are judgements of an expressly non-historical understanding of the past. ${ }^{73}$

This raises questions about history's assemblage. Contingency and touching suggests that history boasts what Oakeshott calls 'inherent continuity', where 'the identity, the oneness, of a length of chain composed of nothing but its links... is itself a function of the continuity of its parts'. ${ }^{74}$ Put in another way, the historian builds what Oakeshott describes as a historical 'dry wall', where the stones (antecedent events) that compose the wall (the subsequent event) are held together not by mortar or any 'extraneous connexion', to use Bradley's phrase, but in terms of their shapes. ${ }^{75}$ The stones' shapes limit what the craftsman can do with his wall, of course, but nor do they fit together exactly. Risking metaphorical muddling, he tells us elsewhere that,

continuity, constitutes a passage of historical change the outcome of which is a subsequent difference'. On Human Conduct, 125.

${ }^{69}$ Quoted in O’Sullivan, Oakeshott on History, 245-246.

${ }^{70}$ On History, 122.

${ }^{71}$ On History, 102-103.

${ }^{72}$ On History, 124-125.

${ }^{73}$ On History, 125-126.

${ }^{74}$ On History, 125.

${ }^{75}$ On History, 102. See F. H. Bradley, Essays on Truth and Reality (Oxford: Clarendon Press, 1914), 362. 'Extraneous connection' is also discussed in Boucher, 'The Creation of the Past', 212. 
[the] product of historical enquiry and imagination is not like the resolution of a jigsaw puzzle, what is on the table being made to correspond to the picture on the lid of the box. There is no such picture and there are no such firm shapes to be picked up and put into their predestined places one at a time. What an historian has are shapes of his own manufacture, more like ambiguous echoes which wind in and out, touch and modify one another; and what he composes is something more like a tune (which may be carried away by the wind) than a neatly fitted together, solid structure. ${ }^{76}$

Historians, then, are craftsman confined to some degree by the pathways of historical change. Inhabiting the present, their interest can only concern evidence of a past in its most incrementally contingent as possible, brought to us by artefacts of a certain configuration for which we piece together an identity as best we can.

Koselleck would find this unnecessarily restrictive. Moreover, absent in Oakeshott's account of studying the historical past compared to Koselleck is the use of other transcendental categories for historical explanation beyond the categories of continuity and change. Nor it seems does he see the relevance or even possibility of studying actors' own conceptions of historical time in order to narrate historical change. Still, there is one particular shift in temporal awareness that Oakeshott does take an interest (as a philosopher, not historian), which is the shifting importance of the future vis-à-vis the present and past in the modern mind-set. This aspect of his thought is highly relevant to his thoughts on the political and is strikingly similar to Koselleck's discussion of the increased separation of the categories of experience and expectation in modernity. I turn to this next.

\section{Modernity and the ideological politics of historical time}

There is ample debate as to how Koselleck's theory of a modern Neuzeit relates to his contemporary theoretical approach to Historik and the plurality of historical times. ${ }^{77}$ As discussed earlier, in his empirical research, Koselleck uses the Sattelzeit as a heuristic device or "temporal indicator ${ }^{78}$ to thematise the temporal orientation of modern concepts. ${ }^{79}$ But he makes sure to separate the thesis from the theory of historical times, claiming that historians must always distinguish attributes of varying temporal layers. 'Those who can change fast, those, who only change slowly, and those, who are most endurable and contain recurring possibilities. Then it is possible to redefine the epoch in such a way that the modern is recognized, but without excluding

\footnotetext{
${ }^{76}$ On History, 126-127.

${ }^{77}$ In her study of feudalism, secularisation and the politics of time, Kathleen Davis criticises Koselleck for relying on an overly simplified form of periodization and supporting 'reductive versions of temporality' in order to differentiate the eschatological temporality of the Middle Ages from the emergence of a historical time in modernity, claiming this compromises his theoretical idea of a plurality of historical times. Kathleen Davis, Periodization and Sovereignty: How Ideas of Feudalism and Secularization Govern the Politics of Time (Philadelphia: University of Pennsylvania Press, 2008), 87-89. Lynn Hunt also reads him as primarily presenting a modernity thesis that fails to explain the precise elements of historical change that lead to a proliferation of historical times. Lynn Hunt, Measuring Time, Making History (Budapest: Central European University Press, 2008), 75-76. Another who focuses on Koselleck's work as a modernity thesis is Peter Osborne in The Politics of Time: Modernity and Avant-Garde (London and New York: Verso, 1995), 13-14. In response, Helge Jordheim trenchantly defended Koselleck by pointing out that Davis and Hunt ignore his repeated emphasis on the layering of time as a push against periodization. Helge Jordheim, 'Against Periodization', 151-171.

${ }^{78}$ The term Sattelzeit was first used (perhaps too carelessly) on a grant application, See Koselleck's remarks in Lehmann and Richter, 'New Studies in Begriffsgeschichte', 69.

${ }^{79}$ See 'The Need for Theory in History', The Practice of Conceptual History, 5 and "'Space of Experience" and "Horizon of Expectation": Two Historical Categories', Futures Past, 263-275.
} 
other epochs as being totally different' ${ }^{80}$ Still, in his research Koselleck remains committed to applying the categories of experience and expectation to identify a period of transition where the changing use of language suggests that a significant shift in temporalization takes place ${ }^{81}$ In the Sattelzeit, 'time does not just remain the form in which all histories take place, but time itself gains a historical quality... history no longer takes place in time, but rather through time. Time is metaphorically dynamicised into a force of history itself ${ }^{82}$ For Koselleck, two temporal features characterise this period of transition. The first is the divorcing of the categories of the space of experience and the horizons of expectation. In the use of concepts like progress, crisis and revolution, a future determined by past experience is eclipsed by a horizon of expectation that is new and open ${ }^{83}$ Cicero's notion of Historia Magistra Vitae turns into Hegel's claim that history has taught us nothing. ${ }^{84} \mathrm{~A}$ second temporal development is the change in how time moves. A defining feature of modernity is the acceleration of time, which is the increasing rate of change brought by technology and industrialisation and the acceleration of temporal rhythms and intervals where periods pass by in shorter and shorter durations ${ }^{85}$ Expectations alter historical time and quickening time alters expectations.

For Koselleck, it is a consequence of this shift in the acceleration and the experience and expectations of historical time that mass political ideologies are born (Ideologieierbarkeit). Within and attached to ideological discourse, Koselleck charts the emergence of a fresh set of practical socio-political concepts, either brand-new or reformulations of older forms, which in their orientation point forwards in the direction of political change and improvement. These modern concepts are part of everyday language used practically by ideologies, or are themselves ideological, in order to explain, persuade, control and manipulate within the political. 'Many basic concepts, above all those designating movements - isms - concur in the demand that future history should differ fundamentally from the past. Among such concepts is "progress," "development," "emancipation," "liberalism," "democratization," "socialism," "communism"”. 86

\footnotetext{
${ }^{80}$ Zeitschichten, 238-239.

${ }^{81}$ This is represented, for example, in the German Historical School's changing the understanding of history from the concept of Historie, a recounting of the past, to Geschichte, a constructed history distilled into a 'collective singular'. See, 'Historia Magistra Vitae: The Dissolution of the Topos into the Perspective of a Modernized Historical Process' Futures Past, 31-42. Koselleck describes this sematic shift as such: 'Kant sought the means by which the planless "aggregate" of human actions could be transposed into a rational "system"...It was the collective singular of Geschichte that rendered such thoughts capable of expression, irrespective of whether it was a matter of world history or of individual history... it was history (Geschichte) conceived as a system that made possible an epic unity that disclosed and established internal coherence...The collective singular...made possible the attribution to history of the latent power of human events and suffering, a power that connected and motivated everything in accordance with a secret or evident plan to which one could feel responsible, or in whose name one could believe oneself to be acting. This philological event occurred in a context of epochal significance: that of the great period of singularization and simplification which was directed socially and politically against a society of estates. Here, Freedom took the place of freedoms, Justice that of rights and servitudes, Progress that of progressions (les progress, the plural) and from the diversity of revolutions, "The Revolution" emerged'. Futures Past, 35.

${ }^{82}$ The Practice of Conceptual History, 165.

${ }^{83}$ The Practice of Conceptual History, 120-127.

${ }^{84}$ Cicero says that 'History is indeed the witness of time, the light of truth, the life of the memory, the messenger of antiquity; with what voice other than that of the orator should it be recommended for immortality?'. De oratore II:9, quoted in 'Historia Magistra Vitae: The Dissolution of the Topos into the Perspective of a Modernized Historical Process'. Quoted in Futures Past, 28. Hegel writes 'that nations and governments have never learned anything from history or acted upon any lessons they might have drawn from it'. Lectures on the Philosophy of World History. Introduction (Cambridge: Cambridge University Press, 1975), 21. Quoted in Futures Past, 38.

${ }^{85}$ See The Practice of Conceptual History, 160-167 and Futures Past, 269. For an expanded (and improved) view of Koselleck's acceleration thesis, see Hartmut Rosa, Social Acceleration: A New Theory of Modernity (New York: Columbia University Press, 2013).

${ }^{86}$ Koselleck's remarks in Lehmann and Richter, 'The Meaning of Historical Terms and Concepts: New Studies on Begriffgeschichte', p. 61.
} 
These concepts, as 'instruments for the direction of historical movement', ${ }^{87}$ demonstrate for Koselleck that the use of political language is also to master the temporal perspectives wrapped within them. ${ }^{88}$ The contestation of historical time thus becomes an essential element of political discourse ${ }^{89}$ In modernity 'time itself becomes a title of legitimation open to occupation from all sides. Specific legitimising concepts would no longer be possible without temporal perspective' ${ }^{90}$

Koselleck's response to the politicisation of historical time is a call to return to a more stable balance between experience and expectation. ${ }^{91}$ His concern over what may be called the 'ideologisation of time' and in particular the future-oriented progressivism of a brand of radical historicism, is a central theme in Critique and Crisis, his published doctoral thesis. Summarising briefly, the book claims that the genesis of the twentieth century political 'crisis' can be traced back to the Enlightenment 'critique' of the absolutist state. The critique was 'transformed into a [historical] process' and 'into the morally just and rational planning of the future by the new elite' ${ }^{92}$ Political ideology, as he sees it, is a consequence of this process - the coordination of ideas and political compulsion - which through temporalized concepts gave rise to singularized philosophies of history. ${ }^{93}$ His prescriptive alternative viewpoint is to accept the permanence of conflict in the political, a view close to Schmitt. ${ }^{94}$ But as Olsen has discussed, unlike Schmitt, Koselleck does not want to enter the ideological debate by politicising the dichotomy of the 'friend' and 'enemy', but instead help to avoid radical historicism-the singularization of history - by promoting his theory of plural historical times. ${ }^{95}$

This aversion to a philosophical historicism again brings Koselleck close to Oakeshott's thinking. Oakeshott agrees with Koselleck that ideologies are foremost a form of political discourse that attach particular meaning to abstract political concepts, and in doing so compare, contrast and compete with other ideologies in the meanings of concepts like liberty, equality and justice. Ideology is 'a vocabulary of beliefs in terms of which to conduct political discourse'. ${ }^{96}$ They can be shorthand, or 'abridgements' to use his phrase, for describing our general dispositions and political cultures, or in the name of change, serve as handbooks for achieving a particular future goal. ${ }^{97}$ Ideologies can be either descriptive or prescriptive and they can offer us greater understanding, lead to fruitful conversation or call for political change. What he calls 'ideological politics', then, is something that 'is not simply politics of principle as against politics

\footnotetext{
${ }^{87}$ See Futures Past, 251. Also see his summary of this argument in 'Time and Revolutionary Language' in Graduate Faculty Philosophy Journal 9:2 (Fall, 1983), 117-127, where he say that 'in our times...Political and social concepts are becoming the navigational instruments of historical movement', 124.

${ }^{88}$ Contrary to the enduring Marxist interpretation, I am arguing here that ideologies are foremost an attempt to harness the meaning of ambiguous or contestable political concepts like liberty, freedom, tradition or community that are produced, utilized and consumed in the political for the purpose of explanation or action. On this conceptual approach see Michael Freeden, Ideology: A Very Short Introduction (Oxford: Oxford University Press, 2003), esp., 45-66, and Freeden Ideology and Political Theory (Oxford: Clarendon Press, 1996), chaps., 1-3.

${ }^{89}$ Koselleck adds, 'The imperative of reorganization stimulates the construction of concepts for the purposes of control and guidance that, in the absence of a temporal perspective of the future, would not have been formulable. The process of temporalization which, as has been shown, began to develop first in historical theory, now entered deep into daily life'. Futures Past, 252.

${ }^{90}$ Futures Past, 248.

${ }^{91}$ See Futures Past, 43-57, and The Practice of Conceptual History, 154-169.

${ }^{92}$ Koselleck, Critique and Crisis: Enlightenment and the Pathogenesis of Modern Society (Cambridge, Massachusetts: The MIT Press), 10.

${ }^{93}$ Critique and Crisis, 183.

${ }^{94}$ On this see Timo Pankakoski, 'Conflict, Conflict, Correctness: Koselleck and Schmitt on Concepts' in Political Theory 38:6 (2010), 749-779.

${ }^{95}$ This is discussed in Olsen, 'Carl Schmitt and Reinhart Koselleck', 204.

${ }^{96}$ Rationalism and Politics, 75.

${ }^{97}$ See Oakeshott, 'Conduct and ideology in politics', in What is History?, 245-254.
} 
of expediency but is a style of politics which springs from attributing to principles a certain character' ${ }^{98}$ As handbooks for political application, ideologies serve the practical interests of change, the defining feature of the practical mode of experience, where the world is consumed with the relationship between the 'what is' and the 'not yet', the 'here and now' and the 'what ought to be'. ${ }^{99}$ Practical change, as opposed to historical change, reflects a very different understanding of the logical counterparts of the past and present. In this case, the present is future oriented and what he calls a 'practical past' used for the present. ${ }^{100}$ The use of the past in practical experience is thus dictated by the unending tension between the real and the ideal. ${ }^{101}$

Oakeshott believes this future-oriented practical mode of experience is a permanent condition from which we cannot escape. It is not a creation of modernity. Yet modernity, loosely set out as it is with Koselleck's Sattelzeit, has reoriented the relationship between the past, present and future, and placed a new set of pressures on the political arrangements of practical life. ${ }^{102}$ Here the past is not used for the practical present, but too often abandoned entirely. In the Politics of Faith and the Politics of Scepticism Oakeshott argues that the appeal of a politics grand plans is a symptom of modernity, coming about in the 'confident and adult language of the eighteenth century'. ${ }^{103}$ During this period, as with Koselleck's Neuzeit, the practical past is no longer connected to and for the present but the present is divorced from it in the name of radical change, where expectation dominates at the expense of experience. 'The vice of contemporary political reflection is to take an excessively long view of the future and an excessively short view of the past... by abridging the pedigree of our political character we restrict our understanding of it' ${ }^{104}$

The main culprit behind this shift is the modern rise of what he terms 'Rationalism', which promotes technical knowledge at the expense of accumulated practical knowledge in the interest of perfecting human conduct. ${ }^{105}$ Rationalism attempts to ignore contingency and inhabit a timeless world, harbouring a 'deep distrust of time, and [an] impatient hunger for eternity and an irritable nervousness in the face of everything topical and transitory' ${ }^{106}$ Political ideologies become useful tools of the Rationalist, and as 'abridgements of tradition' that are 'independently premeditated ${ }^{107}$ they too are abstractions that are meant to transcend time in their applicability.

\footnotetext{
${ }^{98}$ 'Conduct and ideology in politics', What is History?, 248.

${ }^{99}$ Oakeshott says, 'In it the alteration of existence is undertaken. Practical life comprises the attempts we make to alter existence or to maintain it unaltered in the face of threatened change. It is both the production and the prevention of change, and in either case it is not merely a programme for action, but action itself'. Experience and its Modes, 256.

${ }^{100}$ Oakeshott describes the practical temporal outlook as such: 'The present-future of practical engagement composed of subjects of a certain (optative) character related to one another in terms of their desires, purposes and actions and related also to objects, some of which may be recognized to have survived from the past and understood in terms of their alleged worth in the conduct of practical undertakings, is not a shapeless, unspecified encounter with the confusion of all that may be going on, nor is it a mere attitude. It is a coherent, self-sustaining understanding of the world in which a single formal character is imposed upon everything that receives attention'. On History, 22. Oakeshott writes that the practical past exists: 'Wherever the past is merely that which preceded the present, that from which the present has grown, wherever the significance of the past lies in the fact that it has been influential in deciding the present and future fortunes of man...In practical experience, the past is designed to justify, to make valid practical beliefs about the present and the future, about the world in general...the language is that of history, while its thought is that of practice'. Experience and its Modes, 103, 105.

${ }^{101}$ This term is first used by O'Sullivan, Oakeshott on History, 18.

${ }^{102}$ Politics is not itself a mode, but foremost a practical consideration. It is 'the activity of attending to the general arrangements of a set of people whom chance or choice have brought together'. Rationalism and Politics, 44.

${ }^{103}$ Politics of Faith and Politics of Scepticism, 24. Also see Timothy Fuller, 'Michael Oakeshott: the Philosophical skeptic in an impatient age', in Catherine Zuckert ed. Political Philosophy in the Twentieth Century: Authors and Arguments (Cambridge: Cambridge University Press, 2011), 145.

${ }^{104}$ Futures Past, 2.

${ }^{105}$ Rationalism and Politics, 22-23.

${ }^{106}$ Rationalism and Politics, 7.

${ }^{107}$ Rationalism and Politics, 48.
} 
As handbooks they are timeless. Contrary to Koselleck's 'concepts of movement', the value of ideological concepts for Oakeshott is precisely in their historical detachment. 'They compose an understanding of what is to be pursued independent of how it is to be pursued', he tells us. 'A political ideology purports to supply in advance knowledge of what Freedom or Democracy or Justice is, and in this manner sets empiricists to work' ${ }^{108}$ The implementation of ideological politics then brings the timeless into the time-bound world and reorders historical time with new beginnings and ends, revolutions and millenniums, set out in order to change the political.

In this ideological style of politics we see the rapid present-centred differentiation between the 'what ought to be', the 'here and now', and the 'what was', where thanks to ideological slogans, historical time is increasingly disconnected-the future divorced from the past, expectations from experience. Yet while it is cut loose from the past, the future is not open but already predicted. As a response to the plurality of individual ends, the variety of human desires are compromised in favour of communal temporal direction and coherence where goals are already set, the course of action laid out. ${ }^{109}$ This type of historical time is what Oakeshott in On Human Conduct calls an 'enterprise association', where agents are related to each other in agreement upon a common purpose. ${ }^{110}$ Unforeseen contingencies require 'managerial decisions' to do this rather than that in order to procure a wished-for outcome connected with an already agreed upon goal. ${ }^{111}$ Communal enterprise is a symptom of the politics of expectation, where "the activity of governing is understood to be in the service of the perfection of mankind. There is a doctrine of cosmic optimism which, not from observation but as an inference from the perfection of its creator, attributes an unavoidable perfection to the universe...human perfection is sought precisely because it is not present' ${ }^{112}$ As an alternative to individual initiative, the politics of solidarity 'endows government with power and authority such as it has never before enjoyed'113 and often breeds a politics of impatience to accelerate the process by which the 'what is' becomes the 'what ought to be'. In his account of an imagined ill-fated attempt to reach the heavens by building a 'Tower of Babel', Oakeshott says that the slogan 'time flies as the crow flies', ${ }^{114}$ was a particular selling point, and for the Babelian people the catchphrase "Take the Waiting out of Wanting" had bitten deep into their consciousness'. ${ }^{115}$

The impatience of those with a preference for the politics of faith worries Oakeshott. 'We forget that, in order to make the fire burn a little more briskly, we have pulled out all the dampers', he says, 'and in our enjoyment of the warmth we fail to remark that the scuttle is empty and the chimney near to being on fire'. ${ }^{116}$ Like Koselleck, his response to the radical temporality ${ }^{117}$ of modern historical time is to close the gap between experience and expectation,

\footnotetext{
${ }^{108}$ Rationalism and Politics, 48.

${ }^{109}$ For Oakeshott's version of the singularization of time, or thought of as horizons, see, 'On Being Conservative', Rationalism and Politics, 425-426. This has clear ramifications for the role of government: 'Thus, governing is recognized as a specific and limited activity; not the management of an enterprise, but the rule of those engaged in a great diversity of self-chosen enterprises'. Rationalism and Politics, 429.

${ }^{110}$ See On Human Conduct, 114-121.

${ }^{111}$ On Human Conduct, 114-115, 130-131. Oakeshott elaborates that 'an enterprise is a "policy", and enterprise association is a 'managerial' engagement; it is agents related to one another in the substantive activity of choosing performances contingently connected with a common purpose or interest, or of their acknowledgement of such choices and performances as their own'. On Human Conduct, 115.

${ }^{112}$ Futures Past, 23

${ }^{113}$ Rationalism and Politics, 381.

${ }^{114}$ Rationalism and Politics, 466.

${ }^{115}$ On History, 208.

${ }^{116}$ Futures Past, 11.

${ }^{117}$ I take this phrase from Tim Fuller's 'Radical Temporality and the Modern Moral Imagination: Two Themes in the Thought of Michael Oakeshott', in Leslie Marsh and Paul Franco (2012) A Companion to Michael Oakeshott, 120-133.
} 
by reflecting on the importance of the past-present, what he calls 'traditions of behaviour', a concept that itself has a specific temporal dimension:

[It] is not a fixed and inflexible manner of doing things; it is a flow of sympathy. It may be temporarily disrupted by the incursion of a foreign influence, it may be diverted, restricted, arrested, or become dried-up, and it may reveal so deep-seated an incoherence that (even without foreign assistance) a crisis appears. And if, in order to meet these crises, these were some steady, unchanging, independent guide to which a society might resort, it would no doubt be well advised to do so. But no such guide exists; we have no resources outside the fragments, the vestiges, the relics of its own tradition of behaviour which the crisis has left untouched. ${ }^{118}$

To follow this is to accept the limitations of our practical existence. The division between the 'what is' and the 'what ought to be' is always to be remade- 'nowhere in practice is there uninterrupted progress or final achievement'. ${ }^{119}$ A more appropriate role of government is found in a 'civil association', which in contrast to its enterprising counterpart is not managerial but is an arrangement based upon the rule of law. ${ }^{120}$ Faced with unforeseeable contingent challenges, we must employ a procedure to adjudicate disputes based on the accumulative meaning of the law; that is, based on past-present experience and 'general conditions of conduct' in response to contingent challenges. ${ }^{121}$ Thus, the emphasis is on legal reasoning based on antecedent situations. 'The essential character of law lies in its being a product of time'. ${ }^{122}$

In response to the ideological separation of the past-future, he urges us to re-incorporate a past-present tradition into the modern disposition; and on the other hand he is promoting localised traditions, the "vernacular language of civil understanding and intercourse ${ }^{123}$ as an alternative to the temptation to govern on the basis of timeless abstract principles. Put in another way, in both instances he wants to reintegrate an awareness of the continuity of historical time. 'When we acquire a tradition', says Oakeshott, 'we are aware of a past and future as soon as we are aware of a present' ${ }^{124}$ A tradition of behaviour is not static or anachronistic: like the historian's judgement of the past, we should see this view of time as levels of alternations of change and continuity, the continuity of change, where 'all parts of a tradition do not change at once and are potential within it'. This is to follow what Oakeshott calls a 'principle of continuity', whereby the temporal dimensions of historical time are recalibrated in an elusive present. In upholding this principle of continuity, 'authority is diffused between past, present and future; between the old, the new, and what is to come. It is steady because, though it moves, it is never wholly in motion; and though it is tranquil, it is never wholly at rest' ${ }^{125}$ In contrast to the accelerated world of radical ideology, the principle of continuity shows a 'preference for slow, small changes... it is more important for a society to move together than for it to move either fast or far'. ${ }^{126}$ Politics, therefore, is not the pursuit of dreams, but the following of 'intimations' in the here and now. ${ }^{127}$ As offshoot of our

\footnotetext{
${ }^{118}$ Rationalism and Politics, 59. J.G.A. Pocock discusses Oakeshott and his concept of tradition in his essay 'Time Institutions and Action' in Politics, Language, and Time (Chicago: University of Chicago Press, 1989), 233-272.

${ }^{119}$ Experience and its Modes, 291.

${ }^{120}$ Oakeshott also discusses this in 'The Rule of Law', in On History, 129-178.

${ }^{121}$ On Human Conduct, 137, 133.

${ }^{122}$ Oakeshott, 'The Concept of Philosophical Jurisprudence' in Luke O'Sullivan ed. The Concept of Philosophical Jurisprudence: Essays and Reviews 1926-51 (Exeter: Imprint Academic, 2007), 158

${ }^{123}$ On Human Conduct, 122.

${ }^{124}$ Rationalism and Politics, 62.

${ }^{125}$ Rationalism and Politics, 61.

${ }^{126}$ Rationalism and Politics, 396-397.

${ }^{127}$ Rationalism and Politics, 66. For a discussion of this phrase, also see W. H. Greenleaf Oakeshott's Philosophical Politics (London: Longmans, Green and Co., 1966), 54.
} 
rituals, traditions and general practices ${ }^{128}$ intimations are an inheritance from which we should not abandon. To pursue them is the moniker of moderation in an impatient age. ${ }^{129}$

\section{Conclusion}

To sum up, my intention here has been to put Koselleck and Oakeshott in conversation with each other. From this we can take away several conclusions. For both, temporality offers a way of understanding the world. Time is to recognise our 'presentness' in attempting to construct the past. ${ }^{130}$ From here, they encourage us to follow formal ways of explaining the past, and how from the present we are to comprehend the past (or not) in relation to the future. Oakeshott discourages us from this temptation to read the past for the future. The historical past is a reflection from the present that has no bearing on it, while, as in Altdorfer's Alexanderschlacht, Koselleck claims that the past simultaneously contains the present and future. In the political, though, the present is to look towards the future, but it is not to forget the past for practical use. Both thinkers eschew efforts to restart time. As 'experience' or 'traditions of behaviour', the past should not be divorced from present-future expectations. This separation is the danger posed by modern temporalized concepts of movement or those employed in the timeless blueprints provided by the Rationalist use of ideology. As an alternative, we must choose a middle ground between the politics of faith and scepticism: not to hope for a future identical to the past, but one connected to it in its localised diversity. History runs across time and times intersect contingency in innumerable ways. A second theme is how we are to comprehend the relationships between past events or experience. Both encourage temporal pluralism, set out in different ways. Koselleck's approach presents a system of multiple and simultaneous layers of time, each of differing duration and movement that are understood using either repetitive structures or the transcendental categories of experience and expectation. These layers extend 'Janus-faced' towards the past and future. Oakeshott's preference is to see the past in different continuities of change. Thought in this way, it is a whole world explained in myriad ways, told by identifying contingent relationships between events at their most incremental and local. Finally, the idea that Oakeshott's brand of contingency, thought of either historically as the continuity of historical change or politically as the pursuit of intimations based on contingent goings on, might permeate the political present as much as the historical past is the main thought I wish for us to take from this article. In both the historical and practical modes, each with different temporal orientations, the idea of contingency is Oakeshott's request for the recognition of time as continuous and uninfluenced by transcendental laws. Contingency does not denote luck, surprise or radical change. Nor does it invite it. It is a difference or new happening that folds in with the antecedent historical or traditional structures that precede it. His endorsement of the contingencies of continuity of change may be taken as a forceful plea to maintain the continuity of historical time. To break wholesale with our past is folly bound to fail. By pushing back against this temptation, what Koselleck sees as the heart of the modern disposition, Oakeshott is engaging in discourse about the proper nature and meaning of time to our daily lives, and in doing so, he is asking several important questions for our own time: how are we to view our own existence within time and to what degree should temporality influence our political conduct.

\footnotetext{
${ }^{128}$ Intimation as ritual is discussed in Rationalism and Politics, 429.

${ }^{129}$ For more on 'intimations', see Fuller, Editor's Introduction, The Politics of Faith and the Politics of Scepticism, xviii; and William Coates, 'Michael Oakeshott as a Liberal Theorist', Canadian Journal of Political Science 17:4 (1985), 781.

${ }^{130}$ The idea of 'presentness' is discussed at length in Elizabeth Corey, Michael Oakeshott on Religion Ascetics and Politics (Columbia: University of Missouri Press), 65-72.
} 